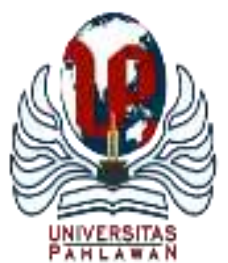

Edukatif : Jurnal Ilmu Pendidikan Volume 3 Nomor 5 Tahun 2021 Halm 3215 - 3228

EDUKATIF: JURNAL ILMU PENDIDIKAN

Research \& Learning in Education

https://edukatif.org/index.php/edukatif/index

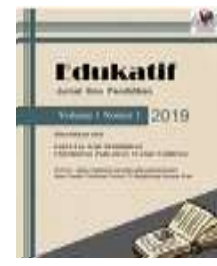

\title{
Keefektifan Media Animasi dalam Meningkatkan Keterampilan Mendongeng pada Siswa Sekolah Menengah Pertama
}

\author{
Mutiara Oktavia Samosir ${ }^{1 凶}$, Wienike Dinar Pratiwi², Een Nurhasanah ${ }^{3}$ \\ Universitas Singaperbangsa Karawang, Indonesia ${ }^{1,2,3}$ \\ E-mail : mutiaraoktaviasamosir22@gmail.com ${ }^{1}$, wienike.dinar@ @kip.unsika.ac.id ${ }^{2}$, \\ een.nurhasanah@staff.unsika.ac.id ${ }^{3}$
}

\begin{abstract}
Abstrak
Rendahnya motivasi berbicara, dan rasa kurang percaya diri menjadikan peserta didik tidak terbiasa mengutarakan gagasannya di depan kelas maupun secara daring. Pembelajaran dongeng yang monoton, dan kurangnya kreativitas pendidik dalam menyediakan pembelajaran juga menjadikan peserta didik kurang dapat memahami. Media pembelajaran sangat penting sebagai penunjang kesuksesan belajar sehingga, peneliti menggunakan media animasi yang diharapkan dapat meningkatkan motivasi dan ketertarikan dalam pembelajaran mendongeng. Penelitian ini menggunakan pendekatan kuantitatif dan metode eksperimen. Populasi dalam penelitian ini adalah seluruh peserta didik kelas VII SMPN 10 Bekasi. Metode pemilihan sampel dalam penelitian ini adalah metode purposive sampling dengan kelas kontrol berjumlah 38 peserta didik dan kelas ekperimen yaitu berjumlah 40 peserta didik. Berdasarkan data yang diperoleh dari hasil postest kemampuan bercerita peserta didik, pada kelas eksperimen memperoleh hasil pretest 34.25 dan hasil postest 68.50. Sementara itu, nilai rata-rata postest kelas kontrol memiliki hasil pretest 32.66 dan hasil postest 54.55. Dilihat dari nilai rata-rata antara pretest dan postest pada kelas eksperimen terdapat peningkatan yang tinggi yaitu 34.25. Sementara itu, nilai rata-rata pretest dan postest kelas kontrol terdapat peningkatan yang cukup tinggi yaitu 21.89. Sehingga, penelitian ini menunjukkan bahwa penggunaan media animasi terbukti lebih efektif digunakan dalam pembelajaran mendongeng.
\end{abstract}

Kata Kunci: keefektifan, media animasi, mendongeng.

\section{Abstract}

Low motivation, and not self-confidence make students not accustomed to expressing their ideas in front of the class or online. The monotonous learning, and low creativity of educators in providing learning also make students hard to understand. Learning media is important to support of learning so researchers use animation media to increase motivation and interest in storytelling. This study uses a quantitative and experimental methods. The population were all students of class VII SMPN 10 Bekasi. The sample selection method was purposive sampling method with 38 students (the control class) and 40 students (the experimental class). Based on the data from the posttest results of the students' storytelling abilities, the experimental class obtained a pretest result of 34.25 and a posttest result of 68.50. Meanwhile, the average posttest score for the control class had a pretest result of 32.66 and a posttest result of 54.55. Judging from the average value between pretest and posttest in the experimental class there was a high increase of 34.25. Meanwhile, the average value of the pretest and posttest of the control class has a fairly high increase, namely 21.89. This study shows that use animation media is more effective in teaching storytelling.

Keywords: effectiveness, animation media, storytelling.

Copyright (c) 2021 Mutiara Oktavia Samosir, Wienike Dinar Pratiwi, Een Nurhasanah

$\triangle$ Corresponding author

Email : 19204090026@student.uin-suka.ac.id

DOI : https://doi.org/10.31004/edukatif.v3i5.1248 
3216 Keefektifan Media Animasi dalam Meningkatkan Keterampilan Mendongeng pada Siswa Sekolah Menengah Pertama - Mutiara Oktavia Samosir, Wienike Dinar Pratiwi, Een Nurhasanah

DOI: https://doi.org/10.31004/edukatif.v3i5.1248

\section{PENDAHULUAN}

Dalam silabus Kurikulum 2013 mata pelajaran bahasa Indonesia diposisikan sebagai pembawa ilmu pengetahuan (Yuniawan, 2014). Salah satu materinya adalah teks narasi. Teks narasi dilakukan melalui kegiatan membaca, menceritakan, menulis, dan menyimak (Makunti, 2019). Karangan narasi menyajikan serangkaian peristiwa dengan arti memberi serentetan kejadian, sehingga pembaca dapat memetik hikmah dari cerita tersebut (Astuti et al., 2014). Teks narasi adalah salah satu jenis teks yang perlu dikuasai peserta didik tingkat sekolah menengah sehingga dapat mengambil hikmah dari dalam teks yang dibaca maupun didengar (Eliya, 2019). Teks narasi dalam silabus termasuk ke dalam materi cerita fantasi salah satunya adalah aspek berbicara yang dapat dituangkan dengan cara bercerita. Bercerita sama halnya dengan mendongeng yang merupakan cerita prosa rakyat yang tidak dianggap benar terjadi, diceritakan untuk hiburan, dan banyak dongeng yang melukiskan kebenaran, mengandung pelajaran moral, atau sindiran (Rukiyah, 2018). Dongeng merupakan salah satu cara untuk mendidik dan menasehati (Utomo, 2013).

Rendahnya motivasi berbicara, kurangnya keterampilan dan, rasa kurang percaya diri pada diri peserta didik saat mendongeng, sehingga peserta didik tidak terbiasa mengutarakan ide/gagasannya didepan kelas. Hal ini didasarkan pada pengalaman pribadi saya melalui observasi di sekolah ketika saya meminta peserta didik untuk bercerita di depan kelas. Salah satu faktor pendorong minat belajar didasari atas ketertarikan untuk belajar (Yunitasari \& Hanifah, 2020). Untuk menumbuhkan minat belajar dibutuhkan dorongan atau gerakan supaya bersifat aktif (Fauziah et al., 2017).

Kegiatan pembelajaran saat ini yang dilakukan secara daring juga menjadi faktor peserta didik kurang aktif. Keterbatasan komunikasi dan interaksi menjadikan minat belajar saat ini menurun (Rusdiantho, 2021). Pengajar selaku edukator yang mengarahkan peserta didik untuk mencapai tujuan pembelajaran dituntut mampu mendesain pembelajaran secara daring dengan media yang tepat (Asmawati, 2020). Hal itu sesuai dengan hasil penelitian yang menyatakan selama proses pembelajaran daring tidak menunjukkan hasil yang baik (Adnan; \& Kainat Anwar, 2020).

Pembelajaran dongeng yang monoton dan kurangnya kreativitas pendidik dalam menyediakan pembelajaran juga merupakan faktor yang menjadikan tidak ada kesan yang mendalam dalam benak peserta didik sehingga peserta didik kesulitan mengingat rangkaian cerita. Kemajuan Teknologi Pendidikan dan Pembelajaran saat ini menuntut untuk menggunakan berbagai media pembelajaran (Nurseto, 2012). Media pembelajaran yang interaktif dapat meningkatkan minat belajar peserta didik (Nugraha et al., 2021). Dalam memecahkan permasalahan, peneliti menggunakan media animasi. Hal itu diperkuat oleh penelitian yang mendapatkan hasil motivasi belajar peserta didik yang menggunakan media animasi lebih tinggi (Sukiyasa \& Sukoco, 2013).

Penelitian yang dilakukan oleh Arif dan Elok dengan judul "Penggunaan Media Pembelajaran Video Animasi Untuk Meningkatkan Hasil Belajar Siswa Smp" menghasilkan dengan bantuan media animasi dapat memingkatkan motivasi dan minat siswa dalam belajar. Penelitian tersebut relevan dengan penelitian ini karena tujuannya untuk mengetahui keefektifan penggunaan media video animasi pada siswa SMP dengan perbedaan penelitiannya yaitu pada materi pembelajarannya (Sudibyo, 2020).

Penelitian selanjutnya dilakukan oleh Zakirman dan Hidayati dengan judul "Praktikalitas Media Video Dan Animasi Dalam Pembelajaran Fisika Di Smp" yang hasilnya bahwa penggunaan bahan ajar video dan animasi meningkatkan pemahaman siswa. Penelitian tersebut relevan dengan penelitian ini karena tujuannya untuk mengetahui keefektifan penggunaan media video animasi pada siswa SMP dengan perbedaan penelitiannya yaitu pada materi pembelajarannya (Zakirman;Hidayati, 2017).

Penelitian dilakukan oleh Ricardus dan teman-teman tentang "Pengembangan Video Pembelajaran Ipa Berbasis Kontekstual Di Manggarai Untuk Belajar Siswa Pada Masa Pandemic Covid-19" dimana hasil penelitian tersebut menyatakan bahwa video pembelajaran dapat digunakan untuk membantu proses belajar 
siswa dari rumah (Ferdinandus \& Ardian, 2020). Penelitian tersebut relevan dengan penelitian ini karena tujuannya untuk mengetahui keefektifan penggunaan media video dan penelitian yang dilakukan pada masa pandemi secara daring pada siswa SMP dengan perbedaan penelitiannya yaitu pada materi pembelajarannya.

Pada penelitian yang dilakukan oleh Nur Laylinaumi Rahmawati yang berjudul "Keefektifan Penggunaan Media Wayang Dongeng Dan Media Fotonovela Dengan Teknik Permainan Resep Gotong Royong Untuk Meningkatkan Keterampilan Bercerita Pada Siswa Kelas Vii Smp". Hasilnya menggunakan media wayang dongeng efektif untuk meningkatkan kemampuan bercerita. Penelitian tersebut relevan dengan penelitian ini karena memiliki kesamaan tujuan untuk meningkatkan keterampilan bercerita siswa kelas VII. Hal yang membedakan adalah jenis media yang digunakan, penelitian ini menggunakan media wayang dongeng dan fotonovela, sedangkan pada penelitian kali ini menggunakan media animasi (Nur Laylinaumi Rahmawati, 2011).

Selanjutnya, berdasarkan penelitian yang digunakan oleh Sandra Novita Sari yang berjudul "Keefektifan Penggunaan Media Ulead dan Media Wayang Dongeng dengan Metode Resitasi Untuk Meningkatkan Keterampilan Mendongeng Pada Siswa Kelas VII SMP”. Penelitian tersebut relevan dengan penelitian ini karena sama meneliti tentang keefektifan penggunaan media pembelajaran untuk meningkatkan keterampilan mendongeng pada siswa kelas VII SMP. Adapun perbedaannya pada media penelitian yang akan digunakan (Sari, 2011).

Terakhir, penelitian oleh Nur Indah Fitriana yang berjudul "Keefektifan Pembelajaran Menceritakan Kembali Teks Fabel Menggunakan Metode Time Token dan Talking Stick Berbantuan Media Video Animasi Pada Peserta Didik Kelas Vii Smp". Penelitian tersebut relevan karena sama meneliti mengenai keefektifan penggunaan media video animasi pada siswa kelas VII. Adapun perbedaan dalam penelitian pada pembelajaran yang diteliti yaitu pembelajaran menceritakan kembali teks fabel. Hasil penelitian tersebut menunjukkan bahwa penggunaan media video animasi dengan metode time token lebih efektif digunakan daripada menggunakan metode talking stick (Nur Indah Fitriana, 2011).

Berdasarkan penjabaran diatas, penelitian tentang keefektifan media animasi untuk meningkatkan keterampilan mendongeng belum banyak dilakukan sehingga, penelitian ini difokuskan untuk meningkatkan keterampilan siswa dalam mendongeng dengan media animasi yang bertujuan untuk mengetahui keefektifan dan respon dari penggunaan media animasi dalam meningkatkan keterampilan mendongeng pada peserta didik kelas VII SMPN 10 Bekasi.

\section{METODE PENELITIAN}

Penelitian ini dilakukan dengan menggunakan pendekatan kuantitatif dan metode eksperimen. Perlakuan yang akan diujicobakan dalam penelitian ini adalah pembelajaran menggunakan media animasi untuk kelas eksperimen dan pembelajaran secara konvensional untuk kelas kontrol. Variabel yang digunakan dalam penelitian ini terdiri atas 2 variabel, yaitu variabel bebas dan variabel terikat. Variabel bebas dalam penelitian ini adalah keefektifan media animasi, sedangkan variabel terikat dalam penelitian ini adalah keterampilan mendongeng. Desain eksperimen yang dipilih adalah Quasi Eksperimental dengan bentuk pretest-posttest Control Group Design.

Populasi dalam penelitian ini adalah siswa kelas VII di SMPN 10 Bekasi dengan jumlah keseluruhan peserta didik 351 yang terbagi menjadi 9 kelas. Pada penelitian ini, jumlah populasi yang diteliti memiliki subjek lebih dari 100, maka peneliti akan mengambil sampel menggunakan teknik purposive sampling. Ditentukan kelas VII E sebagai kelas kontrol dengan pembelajaran konvensional. Kelas VII F sebagai kelas eksperimen yang mendapatkan pembelajaran media animasi. Penentuan sampel ini dengan alasan kelas VII E dan VII F merupakan 2 kelas unggulan, nilai mata pelajaran bahasa Indonesia lebih tinggi dari kelas lainnya, dan murid pada kelas tersebut aktif pada pembelajaran bahasa Indonesia. Untuk mendapatkan data peneliti 
3218 Keefektifan Media Animasi dalam Meningkatkan Keterampilan Mendongeng pada Siswa Sekolah Menengah Pertama - Mutiara Oktavia Samosir, Wienike Dinar Pratiwi, Een Nurhasanah

DOI: https://doi.org/10.31004/edukatif.v3i5.1248

melakukan pengumpulan data dengan cara terjun langsung ke lapangan secara observasi, pemberian tes, dan dokumentasi.

Untuk memperoleh data penelitian, dibuatlah instrumen penelitian tes lisan kemampuan mendongeng yang dilakukan peserta didik secara individu untuk mengetahui kemampuan bercerita peserta didik tentang materi yang akan diberi perlakuan dan diberikan penilaian melalui rubrik penilaian berdasarkan indikator penilaian dari aspek kemampuan bercerita pada instrumen yang akan diujicobakan.

Tabel 1. Kategori dan Rentang Nilai

\begin{tabular}{ccc}
\hline No & Kategori & Rentang Nilai \\
\hline 1 & Sangat Baik & $85-100$ \\
\hline 2 & Baik & $70-84$ \\
\hline 3 & Cukup & $60-69$ \\
\hline 4 & Kurang & $50-59$ \\
\hline 5 & Sangat Kurang & $0-49$ \\
\hline
\end{tabular}

Dalam dua perlakuan pretest dan postest dilakukan penilaian terhadap hasil bercerita peserta didik diukur dengan menggunakan pedoman penilaian yang mengacu pada rubrik penilaian pada tabel 1 di atas untuk mengukur kemampuan bercerita peserta didik.

Data yang diperoleh diolah terlebih dahulu. Data dalam penelitian ini adalah data kuantitatif yang diperoleh dari skor pretest, posttest, dan $N$-Gain. Untuk seluruh pengolahan data menggunakan bantuan software SPSS (Statistical Product and Service Solution) versi 20 window.

Data yang diperoleh berupa hasil tes yaitu pretest dan posttest kelas eksperimen dan kelas kontrol. Kemudian data tersebut dianalisis dengan cara manual seperti di bawah ini.

Nilai Akhir $=\frac{\text { Skor Siswa }}{\text { Nilai Maksimal }} \times 100$

Teknik analisis dalam penelitian ini menggunakan statistik deskripsi dan inferensial. Data peningkatan kemampuan bercerita peserta didik di kelas eksperimen maupun kelas kontrol diperoleh dari data indeks gain.

\section{HASIL DAN PEMBAHASAN PENELITIAN}

Data yang diperoleh dalam penelitian ini adalah data kuantitatif, data tersebut dihasilkan untuk mengetahui kemampuan berbicara peserta didik pada kedua sampel maka diperlukan data dari skor pretest, skor posttest, dan skor N-Gain atau selisih skor pretest dan posttest. Hasil data pretest, posttest, dan N-Gain dari instrumen tes lisan yang terdapat 6 indikator penilaian. Data pretest, posttest, dan N-Gain digunakan untuk mengukur keterampilan berbicara peserta didik. Tes dilakukan dilakukan di kelas yang telah dipilih untuk dijadikan sampel penelitian yaitu, kelas VII F untuk kelas eksperimen dan kelas VII E untuk kelas kontrol. Kelas eksperimen yang menggunakan media video animasi dan pada kelas kontrol menggunakan pembelajaran secara konvensional. Banyaknya peserta didik pada kelas eksperimen 40 dan kelas kontrol 38 peserta didik.

Penelitian ini dilakukan 6 kali pertemuan. Sebelum diberikan perlakuan pada kedua kelas tersebut, terlebih dahulu diberikan pretest yang sama untuk mengetahui kemampuan awal perserta didik. Setelah itu, peserta didik diberikan materi yang diajarkan dalam penelitian ini adalah mendongeng. Setelah itu, untuk mengetahui peningkatan kemampuan berbicara dalam mendongeng pada peserta didik, maka dapat diukur setelah kedua kelas tersebut diberikan perlakuan dan diberikan tes lisan yaitu posttest. Pengolahan data, seluruh perhitungan statistik dalam analisis ini dilakukan dengan bantuan Software SPSS versi 20 for windows. Akan tetapi, ada yang sebagian menggunakan Microsoft Excel 2013 seperti menghitung data NGain. Nilai yang diperoleh peserta didik dan analisis data hasil tes kemampuan berbicara peserta didik sebelum dan sesudah pembelajaran adalah sebagai berikut. 
3219 Keefektifan Media Animasi dalam Meningkatkan Keterampilan Mendongeng pada Siswa Sekolah Menengah Pertama - Mutiara Oktavia Samosir, Wienike Dinar Pratiwi, Een Nurhasanah

DOI: https://doi.org/10.31004/edukatif.v3i5.1248

Tabel 2. Hasil Nilai Pretest dan Postest Kelas Eksperimen

HASIL PRE TEST DAN POST TEST KELAS EKSPERIMEN 7F

\begin{tabular}{|c|c|c|c|c|c|c|c|c|}
\hline & \multicolumn{4}{|c|}{ Pre Test Kelas $7 \mathrm{~F}$} & \multicolumn{4}{|c|}{ Post Test Kelas $7 \mathrm{~F}$} \\
\hline No & Subjek & Hasil & Rentang & Kategori & Subjek & Hasil & Rentang & Kategori \\
\hline 1 & 33 & 56 & \multirow{10}{*}{$50-59$} & Kurang & 1 & 89 & \multirow{5}{*}{$85-100$} & Sangat Baik \\
\hline 2 & 39 & 56 & & Kurang & 36 & 89 & & Sangat Baik \\
\hline 3 & 16 & 54 & & Kurang & 15 & 88 & & Sangat Baik \\
\hline 4 & 32 & 53 & & Kurang & 7 & 86 & & Sangat Baik \\
\hline 5 & 4 & 51 & & Kurang & 9 & 85 & & Sangat Baik \\
\hline 6 & 21 & 51 & & Kurang & 2 & 83 & \multirow[t]{16}{*}{$70-84$} & Baik \\
\hline 7 & 19 & 49 & & Kurang & 25 & 83 & & Baik \\
\hline 8 & 20 & 43 & & Sangat Kurang & 28 & 83 & & Baik \\
\hline 9 & 36 & 43 & & Sangat Kurang & 34 & 83 & & Baik \\
\hline 10 & 27 & 41 & & Sangat Kurang & 23 & 82 & & Baik \\
\hline 11 & 13 & 36 & \multirow[t]{30}{*}{$0-49$} & Sangat Kurang & 8 & 80 & & Baik \\
\hline 12 & 26 & 36 & & Sangat Kurang & 22 & 80 & & Baik \\
\hline 13 & 10 & 35 & & Sangat Kurang & 10 & 77 & & Baik \\
\hline 14 & 28 & 34 & & Sangat Kurang & 26 & 77 & & Baik \\
\hline 15 & 34 & 34 & & Sangat Kurang & 18 & 74 & & Baik \\
\hline 16 & 38 & 34 & & Sangat Kurang & 37 & 72 & & Baik \\
\hline 17 & 40 & 34 & & Sangat Kurang & 5 & 71 & & Baik \\
\hline 18 & 29 & 33 & & Sangat Kurang & 40 & 70 & & Baik \\
\hline 19 & 30 & 33 & & Sangat Kurang & 4 & 69 & & Baik \\
\hline 20 & 1 & 32 & & Sangat Kurang & 19 & 69 & & Baik \\
\hline 21 & 3 & 31 & & Sangat Kurang & 21 & 69 & & Baik \\
\hline 22 & 8 & 31 & & Sangat Kurang & 17 & 68 & \multirow[t]{7}{*}{$60-69$} & Cukup \\
\hline 23 & 23 & 31 & & Sangat Kurang & 39 & 68 & & Cukup \\
\hline 24 & 35 & 31 & & Sangat Kurang & 35 & 65 & & Cukup \\
\hline 25 & 5 & 29 & & Sangat Kurang & 11 & 62 & & Cukup \\
\hline 26 & 11 & 29 & & Sangat Kurang & 31 & 62 & & Cukup \\
\hline 27 & 22 & 29 & & Sangat Kurang & 24 & 60 & & Cukup \\
\hline 28 & 25 & 29 & & Sangat Kurang & 29 & 60 & & Cukup \\
\hline 29 & 6 & 28 & & Sangat Kurang & 13 & 57 & \multirow[t]{11}{*}{$50-59$} & Kurang \\
\hline 30 & 12 & 28 & & Sangat Kurang & 30 & 57 & & Kurang \\
\hline 31 & 37 & 28 & & Sangat Kurang & 6 & 56 & & Kurang \\
\hline 32 & 15 & 26 & & Sangat Kurang & 27 & 56 & & Kurang \\
\hline 33 & 31 & 26 & & Sangat Kurang & 33 & 56 & & Kurang \\
\hline 34 & 14 & 25 & & Sangat Kurang & 16 & 54 & & Kurang \\
\hline 35 & 24 & 25 & & Sangat Kurang & 20 & 53 & & Kurang \\
\hline 36 & 7 & 23 & & Sangat Kurang & 32 & 53 & & Kurang \\
\hline 37 & 9 & 23 & & Sangat Kurang & 12 & 50 & & Kurang \\
\hline 38 & 2 & 20 & & Sangat Kurang & 3 & 49 & & Kurang \\
\hline 39 & 17 & 20 & & Sangat Kurang & 14 & 49 & & Kurang \\
\hline 40 & 18 & 20 & & Sangat Kurang & 38 & 46 & $0-49$ & Sangat Kurang \\
\hline & lah & \multicolumn{3}{|c|}{1370} & \multicolumn{4}{|c|}{2740} \\
\hline
\end{tabular}


3220 Keefektifan Media Animasi dalam Meningkatkan Keterampilan Mendongeng pada Siswa Sekolah Menengah Pertama - Mutiara Oktavia Samosir, Wienike Dinar Pratiwi, Een Nurhasanah

DOI: https://doi.org/10.31004/edukatif.v3i5.1248

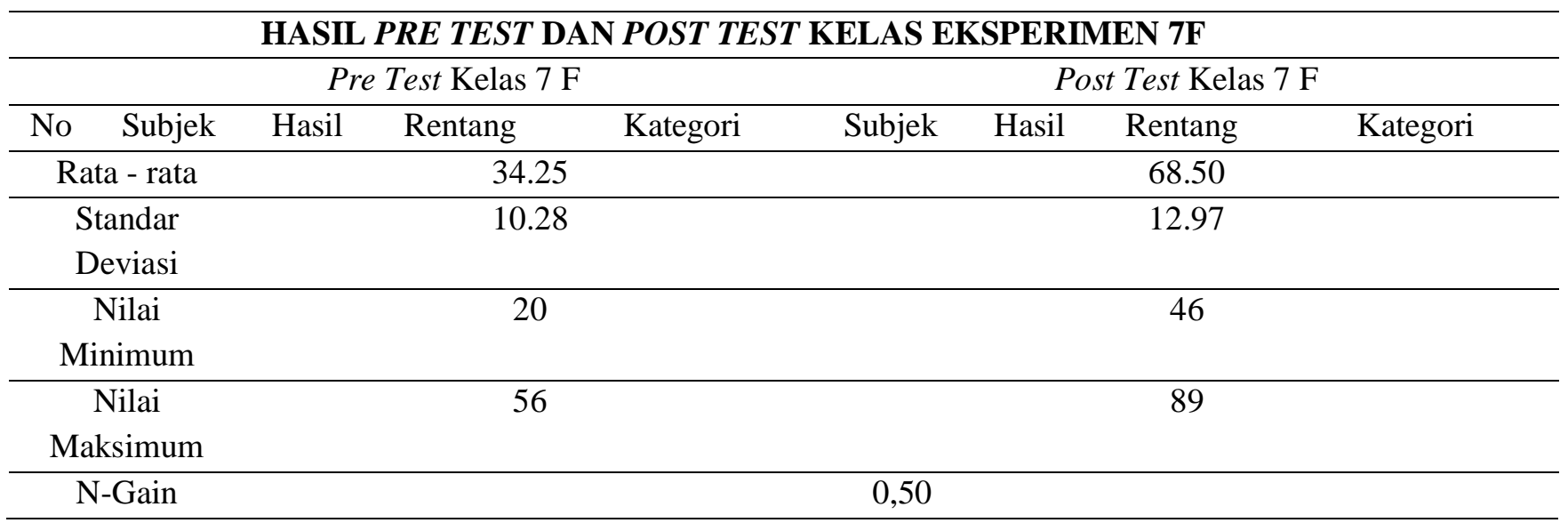

Tabel 3. Hasil Nilai Pretest dan Postest Kelas Kontrol HASIL PRE TEST DAN POST TEST KELAS EKSPERIMEN 7E

Pre Test Kelas $7 \mathrm{E} \quad$ Post Test Kelas 7 E

\begin{tabular}{|c|c|c|c|c|c|c|c|c|}
\hline No & Subjek & Hasil & Rentang & Kategori & Subjek & Hasil & Rentang & Kategori \\
\hline 1 & 12 & 50 & $50-59$ & Kurang & 8 & 71 & $70-84$ & Baik \\
\hline 2 & 8 & 45 & \multirow[t]{29}{*}{$0-49$} & Sangat Kurang & 5 & 68 & \multirow[t]{13}{*}{$60-69$} & Cukup \\
\hline 3 & 25 & 45 & & Sangat Kurang & 17 & 68 & & Cukup \\
\hline 4 & 34 & 39 & & Sangat Kurang & 34 & 67 & & Cukup \\
\hline 5 & 7 & 37 & & Sangat Kurang & 25 & 65 & & Cukup \\
\hline 6 & 24 & 37 & & Sangat Kurang & 11 & 62 & & Cukup \\
\hline 7 & 6 & 36 & & Sangat Kurang & 23 & 62 & & Cukup \\
\hline 8 & 11 & 36 & & Sangat Kurang & 31 & 62 & & Cukup \\
\hline 9 & 23 & 36 & & Sangat Kurang & 15 & 60 & & Cukup \\
\hline 10 & 29 & 35 & & Sangat Kurang & 24 & 60 & & Cukup \\
\hline 11 & 1 & 34 & & Sangat Kurang & 29 & 60 & & Cukup \\
\hline 12 & 9 & 34 & & Sangat Kurang & 2 & 59 & & Cukup \\
\hline 13 & 13 & 34 & & Sangat Kurang & 22 & 59 & & Cukup \\
\hline 14 & 18 & 34 & & Sangat Kurang & 36 & 59 & & Cukup \\
\hline 15 & 26 & 34 & & Sangat Kurang & 7 & 57 & \multirow[t]{16}{*}{$50-59$} & Kurang \\
\hline 16 & 30 & 34 & & Sangat Kurang & 13 & 57 & & Kurang \\
\hline 17 & 33 & 34 & & Sangat Kurang & 30 & 57 & & Kurang \\
\hline 18 & 37 & 34 & & Sangat Kurang & 6 & 56 & & Kurang \\
\hline 19 & 4 & 31 & & Sangat Kurang & 10 & 56 & & Kurang \\
\hline 20 & 5 & 31 & & Sangat Kurang & 27 & 56 & & Kurang \\
\hline 21 & 10 & 31 & & Sangat Kurang & 33 & 56 & & Kurang \\
\hline 22 & 16 & 31 & & Sangat Kurang & 1 & 54 & & Kurang \\
\hline 23 & 17 & 31 & & Sangat Kurang & 16 & 54 & & Kurang \\
\hline 24 & 21 & 31 & & Sangat Kurang & 26 & 54 & & Kurang \\
\hline 25 & 22 & 31 & & Sangat Kurang & 32 & 53 & & Kurang \\
\hline 26 & 27 & 31 & & Sangat Kurang & 4 & 51 & & Kurang \\
\hline 27 & 35 & 31 & & Sangat Kurang & 9 & 51 & & Kurang \\
\hline 28 & 36 & 31 & & Sangat Kurang & 21 & 51 & & Kurang \\
\hline 29 & 2 & 29 & & Sangat Kurang & 12 & 50 & & Kurang \\
\hline 30 & 14 & 29 & & Sangat Kurang & 14 & 49 & & Kurang \\
\hline
\end{tabular}


3221 Keefektifan Media Animasi dalam Meningkatkan Keterampilan Mendongeng pada Siswa Sekolah Menengah Pertama - Mutiara Oktavia Samosir, Wienike Dinar Pratiwi, Een Nurhasanah

DOI: https://doi.org/10.31004/edukatif.v3i5.1248

\begin{tabular}{|c|c|c|c|c|c|c|c|c|}
\hline \multicolumn{9}{|c|}{ HASIL PRE TEST DAN POST TEST KELAS EKSPERIMEN 7E } \\
\hline & \multicolumn{4}{|c|}{ Pre Test Kelas $7 \mathrm{E}$} & \multicolumn{4}{|c|}{ Post Test Kelas 7 E } \\
\hline No & Subjek & Hasil & Rentang & Kategori & Subjek & Hasil & Rentang & Kategori \\
\hline 31 & 19 & 29 & & Sangat Kurang & 19 & 49 & & Kurang \\
\hline 32 & 31 & 29 & & Sangat Kurang & 3 & 46 & $0-49$ & Sangat Kurang \\
\hline 33 & 38 & 29 & & Sangat Kurang & 28 & 46 & & Sangat Kurang \\
\hline 34 & 28 & 26 & & Sangat Kurang & 38 & 46 & & Sangat Kurang \\
\hline 35 & 3 & 23 & & Sangat Kurang & 20 & 43 & & Sangat Kurang \\
\hline 36 & 15 & 23 & & Sangat Kurang & 18 & 34 & & Sangat Kurang \\
\hline 37 & 20 & 23 & & Sangat Kurang & 37 & 34 & & Sangat Kurang \\
\hline 38 & 32 & 23 & & Sangat Kurang & 35 & 31 & & Sangat Kurang \\
\hline \multicolumn{2}{|c|}{ Jumlah } & \multicolumn{3}{|c|}{1241} & \multicolumn{4}{|c|}{2073} \\
\hline \multicolumn{2}{|c|}{ Rata - rata } & \multicolumn{3}{|c|}{32.66} & \multicolumn{4}{|c|}{54.55} \\
\hline \multicolumn{2}{|c|}{$\begin{array}{l}\text { Standar } \\
\text { Deviasi }\end{array}$} & \multicolumn{3}{|c|}{5.81} & \multicolumn{4}{|c|}{9.17} \\
\hline \multicolumn{2}{|c|}{$\begin{array}{c}\text { Nilai } \\
\text { Minimum }\end{array}$} & \multicolumn{3}{|c|}{23} & \multicolumn{4}{|c|}{31} \\
\hline \multicolumn{2}{|c|}{$\begin{array}{c}\text { Nilai } \\
\text { Maksimum }\end{array}$} & \multicolumn{3}{|c|}{50} & \multicolumn{4}{|c|}{71} \\
\hline & Gain & & & & 0,32 & & & \\
\hline
\end{tabular}

\section{Deskripsi Data Hasil Pretest dan Postest Kemampuan Berbicara Peserta Didik Kelas Eksperimen dan Kelas Kontrol}

Deskripsi data pretest dan postest kemampuan berbicara peserta didik kelas eksperimen dan kelas kontrol yang dilakukan dengan menggunakan bantuan Software SPSS versi 20 windows yaitu terlihat pada tabel berikut.

Berdasarkan tabel 2 dan tabel 3 di atas, diketahui bahwa rata-rata kemampuan berbicara peserta didik dari hasil pretest pada kelas eksperimen yaitu 34.25 dan 32.66 pada kelas kontrol. Maka dari itu, dapat dikatakan bahwa kemampuan awal antara kelas eksperimen dan kelas kontrol tidak jauh berbeda. Standar deviasi pretest di kelas eksperimen 10.28 sedangkan di kelas kontrol 5.81. Maka dari itu, melihat hasil tersebut dapat dikatakan bahwa sebaran data kemampuan berbicara peserta didik kelas eksperimen lebih menyebar dari pada kelas kontrol. Nilai minimum dan maksimum hasil pretest kelas eksperimen adalah 20 dan 56, Akan tetapi untuk nilai minimum dan maksimum hasil pretest kelas kontrol adalah 23 dan 50.

Sementara itu, nilai rata-rata postest kemampuan berbicara peserta didik kelas eksperimen dan kelas kontrol masing-masing adalah 34.25 dan 32.66. Sehingga dapat dikatakan, bahwa kemampuan akhir pada kelas eksperimen lebih tinggi daripada hasil kemampuan akhir pada kelas kontrol. Selanjutnya, standar deviasi postest di kelas eksperimen 12.97. Akan tetapi, di kelas kontrol 9.17. Melihat hasil tersebut maka dapat dikatakan bahwa sebaran data peserta didik kelas eksperimen lebih menyebar dari pada kelas kontrol. Nilai minimum dan maksimum hasil postest kelas eksperimen adalah 46 dan 89. Sementara itu, nilai minimum dan maksimum hasil postest kelas kontrol adalah 31 dan 71.

Sementara itu, nilai rata-rata $\mathrm{N}-$ Gain pada kelas eksperimen dari hasil pretest dan postest 0,50 dan nilai rata-rata N-Gain dari kelas kontrol adalah 0.32. Maka dari itu, dapat disimpulkan bahwa nilai rata-rata N-Gain lebih besar kelas eksperimen dari pada kelas kontrol.

Berdasarkan data hasil uraian di atas, maka untuk mengetahui perbedaan yang signifikan data pretest, postest, dan N-Gain antara kelas eksperimen dan kelas kontrol, maka akan dilakukan uji statistik terhadap ketiga data tersebut. 
3222 Keefektifan Media Animasi dalam Meningkatkan Keterampilan Mendongeng pada Siswa Sekolah Menengah Pertama - Mutiara Oktavia Samosir, Wienike Dinar Pratiwi, Een Nurhasanah

DOI: https://doi.org/10.31004/edukatif.v3i5.1248

\section{Analisis Data Pretest Kemampuan Berbicara Peserta Didik}

Hasil pengolahan data pretest didapatkan dari hasil tes kemampuan berbicara peserta didik. Ini dilaksanakan di kelas eksperimen dan kelas kontrol yang dilaksanakan sebelum dilakukannya pembelajaran, bertujuan untuk mengetahui kemampuan awal bercerita peserta didik di kelas eksperimen dan kelas kontrol. Hasil pengolahan data menggunakan bantuan program Software SPSS versi 20 for windows. Hasil penelitian skor rata-rata dan standar deviasi pada masing-masing kelas dapat dilihat sebagai berikut.

Tabel 4. Statistik Deskriptif Data Pretest

\begin{tabular}{cccc}
\hline Kelas & N & Rata-rata & Std. Deviasi \\
\hline Eksperimen & 40 & 34.25 & 10.28 \\
\hline Kontrol & 38 & 32.66 & 5.81 \\
\hline
\end{tabular}

Berdasarkan tabel 4 di atas, terdapat jumlah peserta didik pada kelas eksperimen sebanyak 40 orang, dan pada kelas kontrol sebanyak 38 orang. Nilai rata-rata kemampuan awal peserta didik kelas eksperimen 34.25. Akan tetapi kelas kontrol 32.66. Artinya, nilai kelas eksperimen lebih besar daripada kelas kontrol. Sementara itu, nilai standar deviasi kelas eksperimen adalah 10.28 dan kelas kontrol nilai deviasi nya adalah 5.81. Artinya, bahwa sebaran data kelas eksperimen lebih menyebar daripada kelas kontrol. Berdasarkan paparan di atas, maka akan dilanjutkan dengan pengolahan data. Sebelum dilakukan uji coba perbedaan dua rata-rata, terlebih dahulu dilakukan uji normalitas sebagai prasyarat untuk memilih jenis uji statistik apa yang akan digunakan. Sementara itu, jika data yang berdistribusi normal dilakukan uji homogenitas dan jika data yang tidak berdistribusi normal dilakukan uji non-parametrik.

\section{Uji Normalitas Data Pretest Kemampuan Berbicara}

Pengujian normalitas skor pretest dilakukan untuk mengetahui data dari kedua sampel apakah berdistribusi normal atau tidak. Pengujian normalitas data menggunakan bantuan program Software SPSS versi 20 for windows dengan menggunakan uji Shapiro-Wilk. Hipotesis yang diuji pada data pretest kemampuan berbicara pada kelas eksperimen dan kelas kontrol adalah.

$\mathrm{H}_{0}$ : Skor data kemampuan berbicara berdistribusi normal.

$\mathrm{H}_{1}$ : Skor data kemampuan berbicara tidak berdistribusi normal.

Kriteria pengujian antara lain, jika nilai signifikansi (sig) $\geq 0,05$ maka $\mathrm{H}_{0}$ diterima (data berdistribusi normal) dan jika nilai signifikansi ( $\mathrm{sig}$ ) $\leq 0,05$ maka $\mathrm{H}_{0}$ ditolak (data tidak berdistribusi normal). Berikut ini merupakan hasil perhitungan uji normalitas pretest kelas eksperimen sebelum diberi perlakuan dengan pemberian pembelajaran menggunakan media animasi dan kelas kontrol dengan pembelajaran konvensional yang disajikan dalam tabel di bawah ini.

Tabel 5. Hasil Perhitungan Uji Normalitas Skor Pretest Kemampuan Berbicara

\begin{tabular}{lcc}
\hline \multirow{2}{*}{ Kelas } & \multicolumn{2}{c}{ Shapiro-Wilk } \\
\cline { 2 - 3 } & Df & Sig. \\
\hline Eksperimen & 40 & 0.002 \\
\hline Kontrol & 38 & 0.007 \\
\hline
\end{tabular}

Pada tabel 9 di atas, memperlihatkan bahwa peserta didik yang mengikuti pretest pada kelas eksperimen terdiri dari 40 peserta didik dan kelas kontrol terdiri dari 38 peserta didik. Hasil perhitungan uji normalitas pretest pada kelas eksperimen diperoleh nilai sig sebesar 0.002 . Karena nilai sig $0.002 \leq 0.05$, maka $\mathrm{H}_{0}$ ditolak. Maka dari itu, peneliti menyimpulkan bahwa data sampel pada kelas eksperimen tidak berdistribusi 
3223 Keefektifan Media Animasi dalam Meningkatkan Keterampilan Mendongeng pada Siswa Sekolah Menengah Pertama - Mutiara Oktavia Samosir, Wienike Dinar Pratiwi, Een Nurhasanah

DOI: https://doi.org/10.31004/edukatif.v3i5.1248

normal. Sementara itu, pada kelas kontrol diperoleh sig sebesar 0.007. Karena nilai sig $0.007 \geq 0.05$, maka $\mathrm{H}_{0}$ diterima. Maka dari itu, penulis menyimpulkan bahwa data sampel kelas kontrol berdistribusi normal.

\section{Analisis Data Postest Kemampuan Berbicara Peserta Didik}

Setelah melakukan pengolahan data pretest, kemudian akan dilakukan pengolahan hasil skor postest untuk mengetahui apakah kemampuan akhir berbicara (bercerita) peserta didik kelas eksperimen dan kelas kontrol terdapat perbedaan atau tidak. Hasil pengolahan data menggunakan bantuan program Software SPSS versi 20 for windows. Hasil penelitian skor rata-rata dan standar deviasi pada masing-masing kelas dapat dilihat sebagai berikut.

Tabel 6. Statistik Deskriptif Data Postest

\begin{tabular}{cccc}
\hline Kelas & $\mathbf{N}$ & Rata-rata & Std.Deviasi \\
\hline Eksperimen & 40 & 68.50 & 12.97 \\
\hline Kontrol & 38 & 54.55 & 9.17 \\
\hline
\end{tabular}

Berdasarkan tabel 10 di atas, terdapat jumlah peserta didik pada kelas eksperimen sebanyak 40 dan pada kelas kontrol sebanyak 38. Nilai rata-rata kemampuan akhir peserta didik kelas eksperimen 68.50, sedangkan kelas kontrol 54.55. Artinya nilai kelas eksperimen lebih besar daripada kelas kontrol. Sementara itu, nilai standar deviasi kelas eksperimen adalah 12.97 sementara itu, kelas kontrol nilai standar deviasi nya adalah 9.17. Artinya, bahwa sebaran data kelas eksperimen lebih menyebar daripada kelas kontrol. Berdasarkan paparan di atas, maka akan dilanjutkan dengan pengolahan data. Sebelum dilakukan uji coba perbedaan dua rata-rata, terlebih dahulu dilakukan uji normalitas sebagai prasyarat untuk memilih jenis uji statistik apa yang akan digunakan. Sementara itu, jika data yang berdistribusi normal dilakukan uji Homogenitas dan jika data yang tidak berdistribusi normal dilakukan uji nonparametrik.

\section{Uji Normalitas Data Postest Kemampuan Berbicara}

Pengujian normalitas skor postest dilakukan untuk mengetahui data dari kedua sampel apakah berdistribusi normal atau tidak. Pengujian normalitas data menggunakan bantuan program Software SPSS versi 20 for windows dengan menggunakan uji Shapiro-Wilk. Hipotesis yang diuji pada data postest kemampuan berbicara pada kelas eksperimen dan kelas kontrol adalah.

$\mathrm{H}_{0}$ : Skor data kemampuan berbicara berdistribusi normal

$\mathrm{H}_{1}$ : Skor data kemampuan berbicara tidak distribusi normal

Kriteria pengujian antara lain jika nilai signifikansi ( $\mathrm{sig}$ ) $\geq 0.05$ maka $\mathrm{H}_{0}$ diterima (data berdistribusi normal) dan jika nilai signifikansi ( $\mathrm{sig}) \leq 0.05$ maka $\mathrm{H}_{0}$ ditolak (data tidak berdistribusi normal). Berikut ini merupakan hasil perhitungan uji normalitas postest kelas eksperimen setelah diberi perlakuan dengan pemberian pembelajaran menggunakan media animasi dan kelas kontrol dengan pembelajaran konvensional yang disajikan dalam tabel di bawah ini.

Tabel 7. Hasil Perhitungan Uji Normalitas Skor Postest Kemampuan Berbicara

\begin{tabular}{ccc}
\hline Kelas & \multicolumn{3}{c}{ Shapiro-Wilk } \\
\cline { 2 - 3 } & Df & Sig. \\
\hline Eksperimen & 40 & 0.047 \\
\hline Kontrol & 38 & 0.088 \\
\hline
\end{tabular}

Pada tabel 11 di atas, memperlihatkan bahwa peserta didik yang mengikuti postest baik kelas eksperimen berjumlah 40 peserta didik ataupun kelas kontrol yang berjumlah 38 peserta didik. Hasil perhitungan uji normalitas postest pada kelas eksperimen diperoleh nilai sig sebesar 0.047 . Karena nilai sig $=$ 
3224 Keefektifan Media Animasi dalam Meningkatkan Keterampilan Mendongeng pada Siswa Sekolah Menengah Pertama - Mutiara Oktavia Samosir, Wienike Dinar Pratiwi, Een Nurhasanah

DOI: https://doi.org/10.31004/edukatif.v3i5.1248

$0.047 \leq \alpha=0.05$, maka $\mathrm{H}_{0}$ ditolak. Maka dari itu, penulis menyimpulkan bahwa data sampel pada kelas eksperimen tidak berdistribusi normal. Sementara itu pada kelas kontrol diperoleh sih sebesar 0.088. Karena nilai sig $=0.088 \leq 0.05$, maka $\mathrm{H}_{0}$ diterima. Maka dari itu, penulis menyimpulkan bahwa data sampel dari kelas kontrol berdistribusi normal.

\section{Uji Nonparametrik Mann-Whitney Data Postest Kemampuan Berbicara}

Uji statistik selanjutnya adalah uji nonparametrik Mann-Whitney yang bertujuan untuk melihat uji perbedaan dua rata-rata skor postest kemampuan berbicara peserta didik pada kelas yang menggunakan pembelajaran dengan media animasi (kelas eksperimen) Dan kelas yang menggunakan pembelajaran konvensional (kelas kontrol). Pengolahan data uji nonparametrik Mann-Whitney menggunakan program Software SPSS versi 20 for windows. Kriteria pengujiannya adalah $\mathrm{H}_{0}$ diterima jika nilai sig $\geq 0.05$, dan $\mathrm{H}_{1}$ ditolak. Sementara itu, jika nilai sig $\leq 0.05$, maka $\mathrm{H}_{0}$ ditolak dan $\mathrm{H}_{1}$ diterima. Adapun hipotesis yang diuji adalah.

$\mathrm{H}_{0}: \mu_{1}=\mu_{2}$, tidak terdapat perbedaan antara kemampuan awal berbicara peserta didik yang menggunakan pembelajaran dengan media animasi dan pembelajaran secara konvensional.

$\mathrm{H}_{1}: \mu_{1} \neq \mu_{2}$, terdapat perbedaan antara kemampuan awal berbicara peserta didik yang menggunakan pembelajaran dengan media animasi dan pembelajaran secara konvensional.

Hasil perhitungan uji Nonparametrik Mann-Whitney data postest kemampuan berbicara peserta didik dapat dilihat pada tabel di bawah ini.

Tabel 8. Uji Nonparametrik Mann-Whitney Data Postest Kemampuan Berbicara

\begin{tabular}{cccc} 
Kelas & $\mathbf{N}$ & Mann-Whitney $\boldsymbol{U}$ & Asymp.Sig. (2-Tailed) \\
\cline { 1 - 3 } Eksperimen & 40 & &, 000
\end{tabular}

Berdasarkan tabel 8 di atas memperlihatkan bahwa nilai Asymp.Sig. (2-Tailed) sebesar 0.000. Nilai tersebut lebih besar dari 0.05 ( $\mathrm{sig} \geq 0.05$ ), $\mathrm{H}_{0}$ ditolak dan $\mathrm{H}_{1}$ diterima. Maka dapat disimpulkan bahwa, terdapat perbedaan rata-rata nilai postest kelas eksperimen yang pembelajarannya menggunakan media animasi dengan kelas kontrol yang menggunakan pembelajaran secara konvensional. Artinya, kemampuan kedua kelas tersebut pada pelaksanaan postest berbeda.

\section{Analisis Data N-Gain Kemampuan Berbicara Peserta Didik}

Setelah dilakukan pengolahan data pretest dan postest, selanjutnya dilakukan pengolahan data $\mathrm{N}$-Gain kemampuan berbicara peserta didik. pengolahan $\mathrm{N}$-Gain ini bertujuan untuk mengetahui apakah peningkatan kemampuan berbicara peserta didik pada kelas eksperimen dengan menggunakan media animasi dan kelas kontrol menggunakan pembelajaran konvensional. Maka dari itu, data $\mathrm{N}$-Gain berasal dari selisih skor pretest dengan skor postest berbicara dibagi Skor Maksimum Ideal (SMI) dengan skor pretest. Hasil perhitungan data $N$-Gain disajikan dengan bantuan program Microsoft Excel 2013 pada tabel berikut.

Tabel 9. Hasil Perhitungan Rata-rata dan Kriteria N-Gain

\begin{tabular}{ccc}
\hline Kelas & Rata-rata $N$-Gain & Kriteria \\
\hline Eksperimen & 0.50 & Sedang \\
\hline Kontrol & 0.30 & Rendah \\
\hline
\end{tabular}


Berdasarkan tabel 9 di atas, diketahui rata-rata $N$-Gain kelas eksperimen 0.50 sedangkan kelas kontrol 0.30. Berdasarkan kriteria nilai $N$-Gain Kemampuan berbicara serta didik kelas eksperimen berada pada kriteria sedang, sementara itu kelas kontrol berada pada kriteria rendah.

Penelitian ini dilakukan di salah satu sekolah yang berada di daerah kota Bekasi yaitu, di SMPN 10 Kota Bekasi pada semester genap tahun ajaran 2020/2021. Penelitian ini dilakukan pada sampel dua kelas yaitu, kelas eksperimen pada kelas VII F melakukan pembelajaran dengan menggunakan media animasi, sedangkan kelas kontrol pada kelas VII E Melakukan pembelajaran secara konvensional dengan jumlah peserta didik pada kelas eksperimen yaitu 40, sedangkan pada kelas kontrol yaitu 38. Materi yang akan diajarkan adalah mendongeng sesuai dengan silabus yang ada di sekolah. Pembelajaran dilakukan sebanyak empat kali pertemuan dan dua kali pertemuan untuk pretest dan postest.

Pada awal proses pembelajaran sebelum menggunakan media animasi, kelas eksperimen dan kontrol melakukan pembelajaran konvensional. Peneliti melakukan tes awal atau pretest untuk mengetahui kemampuan awal peserta didik dari kedua kelas tersebut. Sebelum dilakukan pretest pada kelas eksperimen dan kontrol untuk mengetahui kemampuan peserta didik, peneliti menanyakan terlebih dahulu mengenai mendongeng kepada peserta didik. Setelah itu, peneliti mulai melakukan pretest. Akan tetapi, sebelum memulai bercerita peserta didik terlebih dahulu diberikan arahan bahwa orang pertama harus bercerita adalah orang pertama yang ada di dalam daftar hadir. Peserta didik mulai bercerita di depan kelas, ketika itupun guru bahasa Indonesia yaitu Ibu Hernawati mulai menilai kemampuan bercerita peserta didik sesuai dengan indikator yang terdapat seperti diksi, mimik muka, kelancaran, intonasi, keberanian, dan kreativitas unsur intrinsik telah disediakan oleh peneliti.

Selain dilakukannya pretest dengan bercerita di depan kelas, dikarenakan masa pandemi seperti sekarang ini maka dilakukan pretest melalui aplikasi Zoom. Peserta didik masuk ke dalam ruang Zoom, bagi peserta didik yang belum kebagian bercerita di depan kelas diperkenankan bercerita. Dimana di dalam ruang Zoom tersebut, selain peserta didik yg belum pretest, hadir pula Ibu Hernawati untuk menilai kemampuan bercerita peserta didik.

Berdasarkan hasil analisis data pretest kemampuan bercerita peserta didik kelas eksperimen memperoleh nilai rata-rata 34.25 dengan skor ideal 100. Sementara itu, kelas kontrol memperoleh nilai ratarata pretest 32.66 dengan skor ideal 100. Pencapaian nilai sangat kurang tersebut disebabkan kurangnya rasa percaya diri peserta didik dalam bercerita baik di depan kelas maupun melalui aplikasi Zoom. Terbatasnya kemampuan peserta didik dalam mengembangkan kata juga menjadi penyebab pencapaian nilai yang kurang. Selain itu, ada beberapa peserta didik sering melakukan gerak-gerik yang membuat peserta didik lainnya tertawa. Hal itu terjadi di kelas eksperimen maupun di kelas kontrol. Maka dari itu, peneliti dapat menyimpulkan bahwa hasil nilai rata-rata kelas kontrol lebih kecil daripada kelas eksperimen dengan selisih rata-rata nilai pretest dari kedua kelas tersebut hanya 1.59 .

Selanjutnya, peneliti melakukan dengan treatment yang berbeda. Kelas eksperimen melakukan pembelajaran kelas kontrol melakukan pembelajaran. Setelah empat kali pertemuan pembelajaran dengan membedakan perlakuan pada kelas tersebut selanjutnya pada akhir penelitian, peneliti melakukan tes akhir atau postest untuk mengukur kemampuan berbicara peserta didik setelah diberikan treatment pada kelas eksperimen yang melakukan pembelajaran menggunakan media animasi dan pada kelas kontrol yang melakukan pembelajaran secara konvensional. Adapun langkah langkah penggunaan media animasi pada kelas eksperimen adalah sebagai berikut.

1. Peneliti membagikan video animasi yang berjudul "Gajah dan Semut" yang telah peneliti sediakan untuk peserta didik melalui WA grup.

2. Bagi peserta didik yang berada di kelas diperkenankan untuk menonton video animasi tersebut di dalam kelas. Setelah itu menceritakan kembali dongeng yang telah ditonton. 
3. Bagi peserta didik yang mengikuti pembelajaran melalui aplikasi Zoom, maka diperkenankan pula untuk menonton video animasi tersebut, setelah itu menceritakan kembali dongengnya melalui aplikasi Zoom sesuai jam yang telah disepakati sebelumnya dengan peserta didik.

Sementara itu, pemberian postest pada kelas kontrol tidak menggunakan media animasi, hanya melakukan pembelajaran secara konvensional. Berdasarkan data yang diperoleh dari hasil postest kemampuan bercerita peserta didik, pada kelas eksperimen memperoleh nilai 68.50 dengan skor ideal 100 yang berkategori cukup. Hal itu, jika dibandingkan hasil pretest 34.25 dan hasil postest 68.50. Maka dari itu, hasil skor dari pretest dan postest memiliki selisih 34.25. Sementara itu, nilai rata-rata postest kelas kontrol adalah 54.55 dengan skor ideal 100 yang berkategori kurang. Sehingga, jika dibandingkan dengan hasil pretest 32.66 dan hasil postest 54.55 maka memiliki selisih 21.89. Dilihat dari nilai rata-rata antara pretest dan postest pada kelas eksperimen terdapat peningkatan yang tinggi yaitu 34.25. Sementara itu, nilai rata-rata pretest dan postest kelas kontrol terdapat peningkatan yang cukup tinggi yaitu 21.89. Maka dari itu, peneliti dapat menyimpulkan bahwa pembelajaran yang menggunakan media animasi mampu memberi perbedaan peningkatan terhadap kemampuan berbicara pada kelas eksperimen. Artinya, bahwa pembelajaran berbicara peserta didik dengan menggunakan media animasi lebih tinggi tingkat ingatannya sehingga dapat meningkatkan kemampuan berbicara daripada membaca dan mendengarkan. Hasil pengolahan data digambarkan dalam bentuk grafik sebagai berikut.

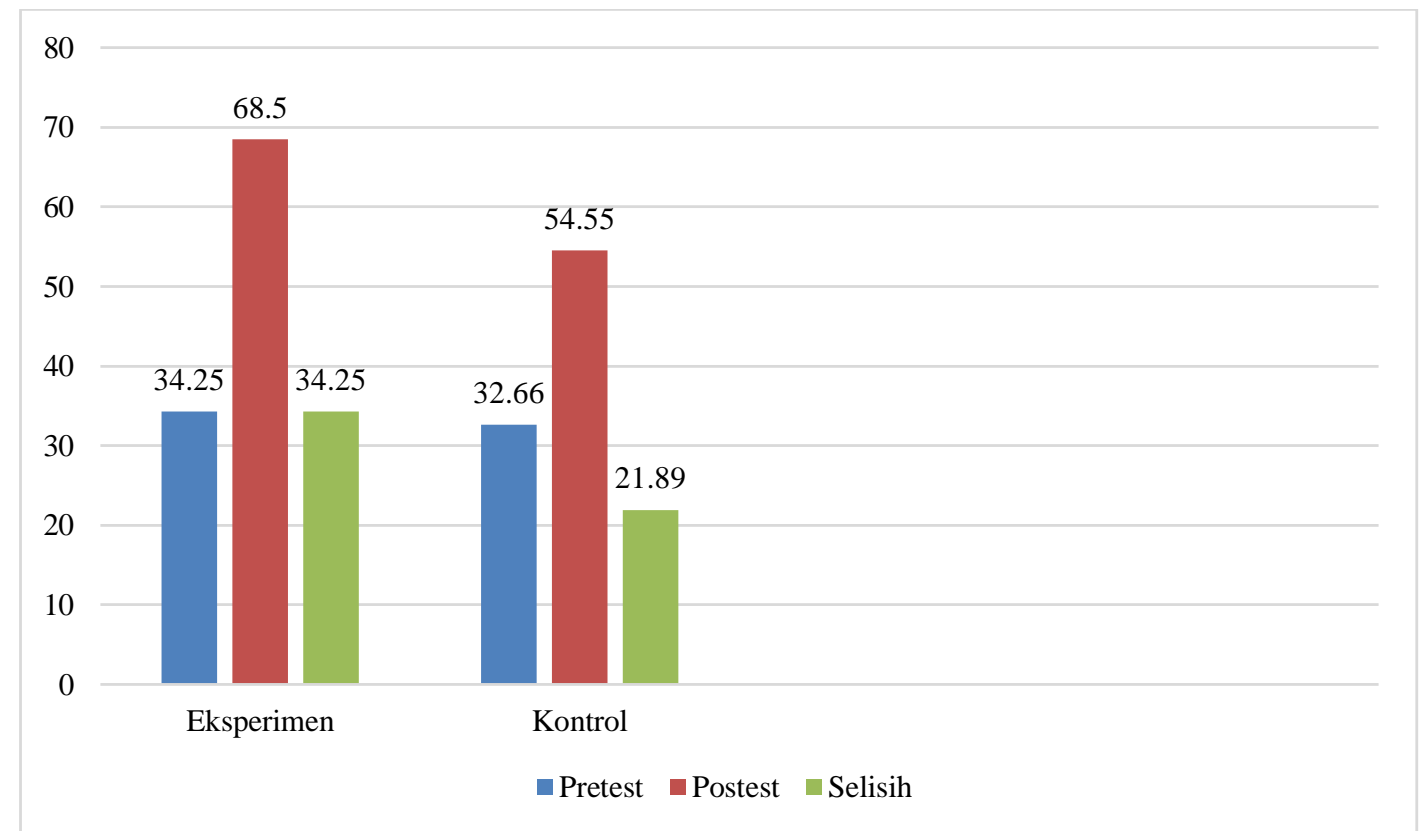

\section{Gambar 1 : Grafik Peningkatan Rata-rata Nilai Pretest dan Postest Pada Kelas Eksperimen dan Kontrol}

Sementara itu, untuk melihat hasil uji hipotesis dua rata-rata dari kedua kelas tersebut diperoleh nilai sebesar 0.000. Dikarenakan $0.000 \leq$ sig 0.05. Maka H0 ditolak. Hal ini menunjukkan bahwa terdapat perbedaan kemampuan akhir atau postest berbicara peserta didik dari kelas eksperimen ataupun kelas kontrol. Selanjutnya untuk lebih jelasnya akan dilanjutkan uji N-Gain, dengan mengambil taraf signifikansi 0.05. Nilai $\mathrm{N}$-Gain yang diperoleh dalam penelitian ini adalah 0.000 . Karena $0.000 \leq 0.05$ maka H0 ditolak. Hal ini menunjukkan bahwa nilai rata-rata N-Gain kemampuan berbicara pada kelas eksperimen lebih baik daripada kelas kontrol yaitu dengan nilai 0.50 untuk kelas eksperimen dan 0.30 untuk kelas kontrol. Kualitas peningkatan kemampuan berbicara peserta didik kelas eksperimen tergolong sedang, sedangkan pada kelas kontrol tergolong rendah. 
Dengan demikian, disimpulkan pada penelitian pembelajaran menggunakan media animasi berpengaruh lebih baik terhadap kemampuan berbicara peserta didik. Artinya, terdapat perbedaan yang signifikan antara kemampuan bercerita peserta didik yang menggunakan media animasi dengan kemampuan berbicara peserta didik yang melakukan pembelajaran secara konvensional. Sementara itu, kelas kontrol terlihat bahwa peningkatan kemampuan berbicara peserta didik pada saat pretest dan postest adalah rendah. Hal itu dibuktikan dengan nilai $\mathrm{N}$-Gain sebesar 0.30. Artinya, rata-rata nilai pretest dan postest tidak terdapat perbedaan. Dengan demikian, dapat disimpulkan bahwa media animasi dapat meningkatkan nilai kemampuan berbicara peserta didik di SMPN 10 Bekasi, hal ini sesuai dengan penelitian sebelumnya yang menyatakan dalam kegiatan pembelajaran menggunakan media video animasi berpengaruh lebih baik pada peserta didik (Sudibyo, 2020) .

Saat penelitian berlangsung, adapun keterbatasan pada penelitian ini yaitu saat pengambilan data para peserta didik sulit untuk diajak mendongeng, pengaturan jadwal yang sulit untuk Zoom, dan keterbatasan tempat juga waktu karena pandemi.

\section{KESIMPULAN}

Berdasarkan pembahasan hasil penelitian di atas mengenai penggunaan media animasi terhadap kemampuan berbicara yaitu dengan materi mendongeng siswa kelas VII di SMPN 10 Bekasi diperoleh kesimpulan bahwa terdapat peningkatan kemampuan berbicara pada peserta didik yang menggunakan media animasi lebih baik daripada peserta didik yang menggunakan pembelajaran secara konvensional.

\section{UCAPAN TERIMA KASIH}

Saya ucapkan terimakasih kepada seluruh pihak yang telah memberikan bantuan selama penulisan penelitian ini baik secara langsung maupun tidak langsung.

\section{DAFTAR PUSTAKA}

Adnan;, M., \& Kainat Anwar. (2020). Online Learning Amid The COVID-19 Pandemic: Students' Perspectives. Journal Of Pedagogical Sociology And Psychology. Https://Doi.Org/Http://Www.Doi.Org/10.33902/JPSP. 2020261309

Asmawati, E. (2020). The Effect Of Using Simple Aircraft Concrete Media On The Mastery Of Concepts In Inquiry Science Learning In Elementary School Students. 12(2).

Astuti, Y. W., Mustadi, A., \& Yogyakarta, U. N. (2014). Jurnal Prima Edukasia, Volume 2 - Nomor 2, 2014. 2, 250-262.

Eliya, I. (2019). Pengembangan Bahan Ajar Menulis Teks Narasi Berbasis Nilainilai Islami Untuk Siswa Mts Di Kabupaten Pemalang. At-Ta'lim: Media Informasi Pendidikan Islam, 18. Https://Doi.Org/Http://Dx.Doi.Org/10.29300/Attalim.V18i2.1923

Fauziah, A., Rosnaningsih, A., Azhar, S., Studi, P., Guru, P., Dasar, S., \& Tangerang, U. M. (2017). Hubungan Antara Motivasi Belajar Dengan Minat5 Belajar5 Siswa Kelas IV SDN Poris Gaga 05 Kota. Jurnal JBSD, 4(2).

Ferdinandus, R. J. F. N. V. S. K. H. M. G. P. N., \& Ardian, A. (2020). Pengembangan Video Pembelajaran Ipa Berbasis Kontekstual Di Manggarai Untuk Belajar Siswa Pada Masa Pandemic Covid-19. Lensa (Lentera Sains): Jurnal Pendidikan IPA, Volume 10, Halaman 63-73. Https://Doi.Org/DOI: 10.24929/Lensa.V10i2.112

Makunti, Y. (2019). Peningkatan Keterampilan Membacakan Media Teks Berjalan Pada Siswa Kelas Viii 
3228 Keefektifan Media Animasi dalam Meningkatkan Keterampilan Mendongeng pada Siswa Sekolah Menengah Pertama - Mutiara Oktavia Samosir, Wienike Dinar Pratiwi, Een Nurhasanah

DOI: https://doi.org/10.31004/edukatif.v3i5.1248

Smp Negeri 2 Tengaran Kabupaten Semarang. 1, 41-52.

Nugraha, F. A., Nur, E., Suryana, Y., \& M, M. R. W. (2021). Edukatif: Jurnal Ilmu Pendidikan Efektivitas Media Powerpoint Dalam Pembelajaran Materi Luas Daerah Segitiga Untuk Meningkatkan Minat Belajar Peserta Didik Di Sekolah Dasar. 3(5), 2760-2768.

Nur Indah Fitriana. (2011). Keefektifan Pembelajaran Menceritakan Kembali Teks Fabel Menggunakan Metode Time Token Dan Talking Stick Berbantuan Media Video Animasi Pada Peserta Didik Kelas Vii Smp. Unnes.

Nur Laylinaumi Rahmawati. (2011). Keefektifan Penggunaan Media Wayang Dongeng Dan Media Fotonovela Dengan Teknik Permainan Resep Gotong Royong Untuk Meningkatkan Keterampilan Bercerita Pada Siswa Kelas Vii Smp. Unnes.

Nurseto, T. (2012). Membuat Media Pembelajaran Yang Menarik. Jurnal Ekonomi Dan Pendidikan, 8(1), 1935. Https://Doi.Org/10.21831/Jep.V8i1.706

Rukiyah. (2018). Dongeng, Mendongeng, Dan Manfaatnya. ANUVA, Volume 2 (, 99-106. Https://Doi.Org/Http://Ejournal.Undip.Ac.Id/Index.Php/Anuva

Rusdiantho, K. S. G. \& E. (2021). Persepsi Mahasiswa Terhadap Pembelajaran Online Fase Pandemic Covid19. Jurnal Edukatif: Jurnal Ilmu Pendidikan, 3(5), 2573-2585. Https://Edukatif.Org/Index.Php/Edukatif/Article/View/899

Sari, S. N. (2011). No Titlekeefektifan Penggunaan Media Ulead Dan Media Wayang Dongeng Dengan Metode Resitasi Untuk Meningkatkan Keterampilan Menyimak Dongeng Pada Siswa Kelas Vii Smp. Unnes.

Sudibyo, A. H. E. (2020). Penggunaan Media Pembelajaran Video Animasi Untuk Meningkatkan Hasil Belajar Siswa Smp. Pensa E-Jurnal: Pendidikan Sains, 8 No 3.

Sukiyasa, K., \& Sukoco, S. (2013). Pengaruh Media Animasi Terhadap Hasil Belajar Dan Motivasi Belajar Siswa Materi Sistem Kelistrikan Otomotif. Jurnal Pendidikan Vokasi, 3(1), 126-137. Https://Doi.Org/10.21831/Jpv.V3i1.1588

Utomo, S. B. (2013). Mendongeng Dalam Perspektif Pendidikan. Jurnal Agastya, 03.

Yuniawan, T. (2014). Mata Pelajaran Bahasa Indonesia. Jurnal Pendidikan Karakter, 1.

Yunitasari, R., \& Hanifah, U. (2020). Pengaruh Pembelajaran Daring Terhadap Minat Belajar Siswa Pada Masa COVID 19. Edukatif: Jurnal Ilmu Pendidikan, 2(3), 232-243. Https://Doi.Org/10.31004/Edukatif.V2i3.142

Zakirman;Hidayati. (2017). Praktikalitas Media Video Dan Animasi Dalam Pembelajaran Fisika Di Smp. Jurnal Ilmiah Pendidikan Fisika Al-Biruni, 06(1), 85-93. Https://Doi.Org/DOI: 10.24042/Jpifalbiruni.V6i1.592 